\title{
Ressignificação do Trabalho Docente ao Ensinar Ciências na Educação Infantil em uma Perspectiva Investigativa
}

\section{Rethinking Inquiry-Based Teacher Practices on Science Education for Children}

\author{
Carla Maline ${ }^{(1)}$ Brasil \\ Eliane Ferreira de Sá ${ }^{(1)}$ Brasil \\ Ely Maués Brasil \\ Alessandra de Caux Souza ${ }^{(1)}$ Brasil
}

Neste artigo analisamos o processo de aproximação de uma professora da Educação de uma abordagem investigativa do ensino de ciências. Para isso, levantamos duas questões: Como as atividades propostas pela professora foram se aproximando de uma perspectiva investigativa? Que deslocamentos de sentidos ocorrem na maneira como a professora compreende o ensino de ciências, ao longo de seu trabalho com as crianças? Os dados da pesquisa foram construídos a partir de uma observação participante, ao longo de oito meses, em uma turma de Educação Infantil de uma escola pública municipal. No percurso da investigação foram realizados vários encontros entre a professora e a pesquisadora para o planejamento e a avaliação das atividades de ensino. Além disso, foram construídos dados por meio: (i) de entrevistas feitas pela pesquisadora com a professora; (ii) dos registros que a professora produziu das atividades didáticas e seus resultados; (iii) das produções das crianças; (iv) do caderno de campo da pesquisadora; (v) de fotografias feitas durante a pesquisa. Os resultados mostram que, ao longo das aulas, a professora criou estratégias didáticas para envolver as crianças nas atividades propostas e acolheu demandas apresentadas pela turma. Desse modo, as crianças compartilharam curiosidades, fizeram observações de fenômenos, realizaram experimentos, desenvolveram sua imaginação e se relacionaram de forma cada vez mais dialogada com a professora e com seus pares. Ao interagir com as crianças e com a pesquisadora, a professora se deslocou de uma visão mais tradicional para uma abordagem mais investigativa do ensino de ciência.

Palavras-chave: Educação Infantil; Educação em Ciências; Ensino por Investigação; Formação de Professores.

In this paper, we describe how a kindergarten teacher has gradually implemented an inquiry-based approach in teaching science. For this matter, we raised two questions: How did the activities proposed by the teacher get closer to an inquiry-based perspective? Which meaning shifts occur due to the teacher's understanding of science teaching 
in her practice with children? The research data were constructed from a participant observation, during eight months, in a kindergarten class of a municipal public school. The data collection involved several sources such as: (i) teacher interviews; (ii) written descriptions of the activities in her classroom and their results; (iii) children's productions; (iv) researcher's field notes; (v) photos taken during the research. The results show that the teacher built teaching and learning contexts that engaged children in the activities proposed and met the expectations held by the group. Thus, the children shared their curiosities, made observations of phenomena, conducted experiments, developed their imagination, and interacted by talking to the whole group. Throughout the interaction with the children and the researcher, the teacher moved from a more traditional to a more inquiry-based approach in teaching science.

Keywords: Kindergarten Education; Science Education; Inquiry-based Teaching; Teacher training.

\section{Introdução}

A Educação em Ciências é um campo do conhecimento extenso, bem estabelecido na área pesquisa em Educação, mas com pouca reflexão acerca de sua contribuição para a Educação Infantil. Embora as produções que envolvem a Educação Infantil estejam crescendo e intensificando o debate sobre como a criança pequena se desenvolve, o que e como ela deve aprender, os estudos que caracterizam a formação, necessidades e práticas das professoras no trabalho com Ciências da Natureza com as crianças pequenas ainda são incipientes.

Ao dizer de Educação em Ciências ou Ensino de Ciências na Educação Infantil é preciso ressaltar que não estamos defendendo o currículo compartimentado em disciplinas. Este nível de ensino se caracteriza principalmente pela abordagem transdisciplinar em que a criança, sujeito de cultura, interage mediada por produtos culturais humanos e pelo "outro". Vygotsky atribui papel fundamental às interações sociais entre indivíduos para a aprendizagem e desenvolvimento, na medida em que qualquer ação humana é sempre mediada por instrumentos e símbolos, utilizados como ferramentas mentais. Para ele as funções mentais superiores têm sua origem no âmbito social (interpessoal) e progressivamente vão sendo internalizadas pelo sujeito (intrapessoal) (Vygotsky, 2001).

Por outro lado, ao trazer a temática da Educação Infantil para a Educação em Ciências, encontramos resistência em uma tradição que considera que crianças tão novas não podem aprender tais conteúdos. Jonh Dewey, discutia em 1902, sobre essa visão quando escreveu:

Uma vez ouvi uma mulher muito inteligente dizer que não conseguia entender como é que as ciências podiam ser ensinadas a uma criança pequena, pois não percebia como é que ela poderia compreender (...) não conseguia perceber como é que se podia ensinar, de que maneira fosse, ciências. Antes de sorrirmos desta observação devemos perguntar 
a nós próprios se ela se encontra sozinha nesta consideração ou se simplesmente formula o princípio subjacente a quase toda a nossa prática escolar. (Dewey, 2002, p. 73).

Essas ideias são ainda hoje habituais entre professores e pesquisadores. Esse pensamento se materializa na prática de nossa sala de aula, quando estudos revelam, que o tempo dedicado à aprendizagem de ciências na Educação Infantil é pequeno, quando comparados ao de outras áreas do conhecimento (Greenfield et al. 2009).

Ao falar de Educação em Ciências buscamos dar centralidade à importância dos conhecimentos das ciências da natureza, cultural e socialmente construídos e sistematizados aos quais todas as crianças têm direito, e nem todas têm acesso. Não possibilitar o acesso da criança aos conhecimentos do mundo natural significa contribuir na desvalorização destas como sujeitos sociais. Nesse sentido, vários pesquisadores indicam a importância da aprendizagem de ciências para as crianças pequenas, seja da Educação Infantil ou dos anos iniciais do Ensino Fundamental: Coutinho et al. (2017); Goulart e Roth (2010); Roth et al. (2013); Eshach (2006); Fumagalli (1998); Charpak (1996); Kamii e Devries (1985).

Em práticas pedagógicas da Educação Infantil, principalmente as que trabalham por projetos é possível identificar que as ciências saem do periférico para uma maior centralidade. São situações planejadas buscando responder a demandas de projetos da turma ou da proposta da escola como um todo. Muitas vezes são trabalhos com equívocos e ênfase na verbalização e acúmulo de informações. $O$ fato é que, de um modo ou de outro, existe uma demanda pelo trabalho de ciências da natureza, embora muitas vezes as professoras não se deem conta de sua amplitude. Nas feiras de cultura de escolas de Educação Infantil em que temos atuado, seja como professores ou formadores de professoras, é considerável o número de trabalhos apresentados que envolvem temáticas das ciências da natureza, principalmente relacionados à área da Biologia: educação ambiental, projetos sobre animais (pássaros; galinha; leão, borboleta, insetos, cada um em uma turma diferente).

Os projetos de trabalho ou sequências de atividades de ciências da natureza realizados na Educação Infantil são muitas vezes motivados por uma questão, um problema do grupo, algo que se queira saber. Porém, em geral, o modo de "investigar" se limita a uma busca de informações já construídas, em fontes autorizadas, como livros de ciências, vídeos, internet. Desse modo, a criança apreende as informações, visto que nesta faixa etária a memória está em pleno desenvolvimento, e as professoras, encantadas, acreditam ter alcançado o objetivo de ensinar ciências. A ênfase na verbalização dá suporte também à avaliação do que as crianças aprenderam. Assim, as crianças internalizam a ideia de que aprender é saber falar bem sobre determinado assunto. É claro, que isso não é privilégio da Educação Infantil, está presente em todos os níveis de ensino.

Ultrapassando essa perspectiva, encontramos professores e pesquisadores do campo de Educação em Ciências voltados ao estudo e implementação de práticas mais significativas para alunos e professores, como as propostas de atividades de 
conhecimento físico de Kamii e Devries (1985), e Carvalho (1998), as proposições de Charpak (1996) quanto às atividades do tipo "mão na massa" e as propostas curriculares Preschool Pathways to Science (PrePS) (Gelman, \& Brenneman, 2004) e ScienceStart (French, 2004), entre outras. Em comum nessas propostas existe o esforço de desenvolver orientações numa perspectiva investigativa.

A aprendizagem por investigação é uma estratégia que a professora pode utilizar para aproximar as crianças das ciências no cotidiano escolar. Nessa perspectiva, o aluno é posto a resolver e levantar problemas, observar, manipular, levantar hipóteses, comparar, classificar, identificar padrões e comunicar seus resultados (Sá, Lima, \& Aguiar, 2011). Contudo, ao trabalhar com as crianças ciências como investigação, a mediação e a postura da professora são fundamentais para que as atividades se configurem como investigativas.

Neste artigo analisamos o processo de aproximação de uma professora da Educação Infantil de uma abordagem investigativa do ensino de ciências. Para isso, discutimos duas questões: Como as atividades propostas pela professora foram se aproximando de uma perspectiva investigativa? Que deslocamentos de sentido ocorrem na maneira como a professora compreende o ensino de ciências, ao longo de seu trabalho com as crianças?

\section{Desafios Postos ao Ensino de Ciências na Educação Infantil}

O campo de Ensino de Ciências, diversificado e amplo, ainda dedica pouco investimento em pesquisas na Educação Infantil. Segundo Colinvaux (2004), isso se deve principalmente a ideias equivocadas que ainda hoje permeiam esse nível de ensino, como: 1) as crianças não teriam condições de aprender algo tão abstrato, complexo e difícil; e 2) ensinar ciências para crianças é uma tarefa impossível, uma vez que, os educadores que irão trabalhar na Educação Infantil, não são formados nas áreas científicas e, portanto, não dominam os conhecimentos científicos. Esses dois desafios que a Educação em Ciências na Educação Infantil enfrentam são fundamentados em crenças que pressupõem faltas e limitações na criança e na professora. Chamamos a esses dois padrões de pensamento de crenças quanto ao déficit cognitivo da criança $\mathrm{e}$ crenças quanto ao déficit de conteúdo da professora.

A crença no déficit cognitivo da criança, considera que a aprendizagem das ciências necessita de um raciocínio abstrato e de ferramentas lógico-matemáticas sofisticadas que as crianças pequenas não possuem. Em uma pesquisa de revisão realizada com crianças dos primeiros anos do Ensino Fundamental, Metz (1995) levanta três pontos de vista ultrapassados sobre as limitações do pensamento das crianças pequenas que são amplamente aceitas pelos profissionais da Educação. São eles:

1. As crianças pequenas pensam em termos concretos em oposição a termos abstratos. Dessa forma o ensino e a aprendizagem em ciências deve-se restringir a atividades de observação e manipulação concreta de materiais e objetos, relegando atividades que necessitam do pensamento abstrato para anos posteriores. 
2. As crianças pequenas dão sentido ao seu mundo, principalmente em termos de ordenação e classificação de objetos e relações, e não em termos de entendimento explicativo ou construção de teorias intuitivas.

3. As crianças pequenas não podem usar a exploração e a experimentação para desenvolver suas ideias.

Esses argumentos são, de certo modo, amparados em interpretações das teorias construtivista de Piaget e sócio-histórica de Vygotsky. Vários autores (French, \& Woodring, 2013; Gelman, \& Brenneman, 2004; Hapgood, Magnusson, \& Palincsar, 2004; Metz, 1995), por exemplo, consideram que os trabalhos de Piaget (1970), subestimam as habilidades cognitivas das crianças, principalmente nos estágios pré-operatório e operatório-concreto. Isso porque, de acordo com Piaget, crianças pequenas, nessas fases, podem usar e formar símbolos para representar seus pensamentos, isto é, palavras, sinais e imagens, mas não são capazes de desenvolver esquemas conceituais e pensamentos abstratos. Além disso, não têm as habilidades cognitivas de fazer inferências, controle de variáveis ou desenvolver explicações. De modo semelhante, Vygotsky $(1996,2001)$ descreve o percurso genético do desenvolvimento do pensamento conceitual em três fases: pensamento sincrético, pensamento por complexos e pensamento por conceitos, sendo que a última fase só é estabelecida na adolescência. Assim, segundo Vygotsky (2001), o processo de formação de conceitos está diretamente relacionado às etapas de seu desenvolvimento. Nas palavras do autor:

O desenvolvimento dos processos que finalmente culminam na formação dos conceitos começa na fase mais precoce da infância, mas as funções intelectuais que, numa combinação específica, constituem a base psicológica do processo de formação de conceitos amadurecem, configuram-se e se desenvolvem somente na puberdade (Vygotsky, 2001, p. 167).

Tais pontos de vista contribuem para o pressuposto de que muitas práticas científicas não seriam adequadas ao desenvolvimento das crianças pequenas, uma vez que consideram que o pensamento da criança é concreto e que, para a aprendizagem de ciências, é necessário o pensamento abstrato. Assim, as crianças pequenas teriam habilidades limitadas para aprender ciências, uma vez que a ciência envolve "uma combinação de princípios abstratos e experimentação controlada com múltiplas variáveis" (French, \& Woodring, 2012, p. 9).

Acreditamos que interpretações pontuais da psicologia cognitivista de Piaget e sócio-históricas de Vygostky, que não consideram o todo da obra desses dois pesquisadores, levam a conclusões equivocadas sobre o potencial da criança pequena de aprender ciências, pois, "essa ótica caracteriza a criança como incompleta ou, no máximo, possuidora de concepções intuitivas" (Coutinho, Goulart, \& Pereira, 2017, p. 3).

De fato, nos últimos trinta anos as pesquisas em cognição e desenvolvimento demonstram que as crianças pequenas são biologicamente e cognitivamente capazes de explorar o mundo natural (French, 2004; Eshach, 2006; Piekny, Grube, \& Maehler, 
2014, Sandoval et al., 2014; Monteira, \& Jiménez-Aleixandre, 2015), assim como estão aptas a correr, falar, brincar imaginar, simbolizar e interagir com as pessoas e o meio físico. Essas pesquisas indicam que a capacidade de aprender de uma criança depende de uma relação complexa de vários fatores como a maturação, os processos de mediação, suas experiências anteriores, os contextos, o domínio de conhecimento, dentre outros. Assim, o desenvolvimento cognitivo de uma criança não é uma simples função da idade, mas depende em grande parte das experiências e explorações anteriores que essa criança faz no mundo. As crianças pequenas criam representações mentais quando investigam o seu entorno. Constroem conhecimentos, dão sentido às experiências vivenciadas. Eles utilizam prontamente novas palavras para descrever, compartilhar e ressignificar essas representações mentais avançando em seus patamares de compreensão. Resumidamente, essas pesquisas informam que crianças muito pequenas têm teorias intuitivas do mundo físico, biológico, psicológico e social, que são semelhantes às teorias científicas, possuindo representações abstratas, estruturadas, coerentes e causais do mundo à sua volta.

Nesse sentido, as crianças são protagonistas de seu crescimento e desenvolvimento, são sujeitos ativos produtores de cultura. Elas possuem uma capacidade de construir de forma sistematizada, modos de significação do mundo. Acreditamos que a abordagem de ensino por investigação com as crianças pequenas potencializa esse protagonismo ampliando as capacidades das crianças de observar, generalizar, manipular, classificar, indagar, comunicar. Enfim, tal abordagem pode expandir suas possibilidades de exploração do mundo natural, de modo cada vez mais sofisticado e próprio.

A crença do déficit de conteúdo da professora considera que a menor ocorrência de propostas consistentes de ensino e aprendizagem de ciências na Educação Infantil se deve ao fato de a professora desse nível de ensino ter um conhecimento de conteúdo em ciências limitado. Essa crença tem como pano de fundo o debate de quem é mais apto a ensinar ciências na Educação Infantil e anos iniciais: pedagogos ou professores de ciências, e que um bom conhecimento dos conteúdos de ciências é condição necessária para ensinar ciências aos pequenos. Tal discussão atinge as concepções de formação dos pedagogos que atuam tanto nos anos iniciais do Ensino Fundamental quanto na Educação Infantil.

As pesquisas que fundamentam a crença de que professoras generalistas possuem capacidades limitadas para ensinar ciências se iniciaram nas investigações que levantavam as concepções prévias dessas professoras sobre temas e conteúdos das ciências da natureza. Esses levantamentos, que datam do início da década de 1990, indicavam que as concepções prévias de grande parte das professoras referentes a conceitos básicos de ciências como eletricidade, estações do ano, fases da lua, fotossíntese, energia, entre outros, eram bem próximas das explicações dadas por crianças de onze anos (Schoon, \& Boone,1998).

Do mesmo modo, os estudos de Carlsen (1991) e Lee (1995) também corroboram esse panorama quando revelam que professores com um conhecimento de conteúdo limitado, restringem as interações discursivas durante as aulas, utilizando 
questões simples que exigem pouca habilidade cognitiva dos alunos, planejam aulas mais estruturadas e, muitas vezes, assemelham-se a professores que possuem pouca experiência docente. Essas investigações se relacionam com a crença do déficit de conteúdo da professora, pois indicam que um bom entendimento do conhecimento de conteúdo é um ingrediente vital para o ensino e aprendizagem das crianças pequenas e que os professoras não podem ensinar bem, o que não conhecem.

No entanto, vários autores (Golby, Martin, \& Porter, 1995; Lima, \& Maués 2006) fazem críticas contundentes a essas investigações, argumentando que as mesmas pesquisas promovem um modelo de formação inicial e desenvolvimento profissional fundamentado no déficit de conhecimento de conteúdo da professora. A lógica desse modelo estabelece uma ideia de ineficácia da Educação em Ciências na Educação Infantil e primeiros anos do Ensino Fundamental cujo principal ator é o professor e seu limitado conhecimento de conteúdo. Disso decorrem, cursos, processos de desenvolvimento profissional e produção de materiais didáticos que têm como pressuposto que o conhecimento do professor sobre temas da ciência pode ser remediado ou transformado para um conhecimento de conteúdo apropriado e que, depois, este pode ser transferido para as crianças.

Consideramos que os defensores do modelo do déficit de conhecimento de conteúdo da professora apresentam contradições. Acreditamos que não é possível transpor de forma direta resultados de pesquisas sobre a influência do conhecimento de conteúdo realizados com professores especialistas do Ensino Médio ou anos finais do Ensino Fundamental para professoras da Educação Infantil e primeiros anos do Ensino Fundamental. A lógica formativa dessas professoras, bem como desses segmentos de ensino fundamentam-se em um conhecimento de conteúdo em ciências interdisciplinar e de menor complexidade. Além disso, os defensores do déficit de conteúdo das professoras não deixam claro o que significa ter um bom entendimento do conhecimento de conteúdo para professoras da Educação Infantil e primeiros anos do Ensino Fundamental. Defendemos a importância de pesquisas que apresentem boas práticas e não que apenas apontem limitações das professoras. Nesse sentido, concordamos com Lima e Maués (2006) quando afirmam:

$\mathrm{O}$ discurso sobre os professores guarda uma crença equivocada de que as pesquisas sobre o domínio conceitual fornecem ferramentas ou saberes para uma intervenção autorizada sobre o que se deve ensinar, ser e fazer com as crianças. Ao contrário disso, compartilhamos da ideia de que é preciso construir um outro olhar, de outro lugar para se compreender o fazer e a constituição da professora. (Lima, \& Maués, 2006, p. 167).

Novamente estamos diante de um problema de alteridade, uma vez que as pesquisas e processos de desenvolvimento profissional fundamentados na crença do déficit de conteúdo da professora não reconhecem a professora da Educação Infantil e dos primeiros anos do Ensino Fundamental como um "outro". Os defensores desse modelo, geralmente são pesquisadores e formadores de professores da área de Educação em Ciências graduados em Biologia, Física e Química. Eles olham para os educadores 
desses níveis de ensino com a visão do especialista, enxergando apenas desconhecimentos, erros, senso comum e lacunas onde poderiam identificar inteligência prática, sabedoria, perspicácia e prudência.

Acreditamos que é preciso entender a criança e a professora como protagonistas dos processos de ensino e aprendizagem, destacando suas potencialidades, percebendoas como outros. Nesse sentido, a criança não é um adulto em construção ou um sujeito inacabado, tampouco a professora é uma profissional com um limitado conhecimento de conteúdo. Consideramos que a proposta de ensino por investigação pode ser um caminho promissor, do ponto de vista da criança, sujeito potente que constrói sentidos sobre o mundo natural. Tais processos de investigação devem ser espaços permanentes nos quais a criança possa se expressar, questionar, opinar, imaginar, observar, experimentar e narrar. No que se refere à professora, a perspectiva investigativa lhe propõe o desafio de considerar a aprendizagem dos pequenos como a possibilidade de atribuir sentido às suas experiências, sendo o adulto capaz de nutrir nelas o interesse, a curiosidade, a indagação, favorecendo o engajamento das crianças pequenas em seus próprios processos de construção de conhecimentos.

\section{O Ensino de Ciências e a Investigação na Educação Infantil}

Alguns estudos apontam que muitas professoras têm dificuldades em promover um ambiente desafiador, propício à investigação e à construção de conhecimentos de ciências na Educação Infantil e primeiros anos do ensino fundamental (Viecheneski, \& Carletto, 2013; Lima, \& Santos; 2013; Lima, \& Maués, 2006; Sasseron, \& Carvalho, 2008).

Nesse sentido, os documentos oficiais como as Diretrizes Curriculares Nacionais para Educação Infantil (MEC, 2010) e as Proposições Curriculares para a Educação Infantil (SMED/PBH, 2011) defendem que a exploração do mundo natural pode gerar novas possibilidades para a ampliação das experiências da criança consigo mesma e com os outros e para a construção de conhecimentos acerca do meio no qual ela está inserida.

Os eixos que norteiam o currículo da Educação Infantil, em geral, são as interações e as brincadeiras, por meio dos quais a criança indaga o mundo e busca conhecê-lo antes mesmo de sua inserção na escola.

Essa concepção de ciências e de currículo nos remete à perspectiva sócio histórica referenciada em Vygotsky (1991). Para esse autor, todo conhecimento é construído socialmente, no contexto das relações humanas. A educação só acontece na relação entre o eu e o outro. Nessas relações, tanto quem aprende quanto quem ensina está inserido no mesmo processo. Além dessa relação, estamos em constante interação com símbolos, signos culturais e objetos. O pensamento de Vygotsky admite a influência da natureza sobre o homem que, por sua vez, também age sobre a natureza e a recria. Assim, o indivíduo é um ser ativo, capaz de modificar a si e ao meio em que vive, por meio de práticas sociais. Desta forma, a criança aprende e, então, se desenvolve.

Nos primeiros contatos das crianças com a aprendizagem de ciências, a linguagem 
científica é apresentada no espaço coletivo da sala de aula, por meio de brincadeiras, de forma que todas as crianças possam usar vocabulários próprios e ir ampliandoos com sentido próprio. Entretanto, é necessário que a professora tenha habilidade, disponibilidade e capacidade de orientar os alunos na aprendizagem das ideias que se quer explorar (Lima, \& Santos 2015).

De uma maneira geral, as crianças têm grande curiosidade sobre mundo natural. Não se cansam de perguntar o porquê, mesmo que os adultos não demonstrem interesse em respondê-las. As crianças estão sempre dispostas a testar suas hipóteses e apresentam características importantes para se construir novos conhecimentos. Essa postura das crianças pode ser aproveitada e explorada quando a professora traz atividades com abordagem investigativa para o espaço coletivo da sala de aula.

No Brasil, essa abordagem de ensino vem ganhando força nas últimas décadas. Uma das evidências é o crescimento significativo do número de publicações sobre ensino por investigação desde os anos 2000. Contudo, ainda há uma polissemia na literatura acerca de como definir uma atividade investigativa. Mas existem características que podem nos ajudar a caracterizar uma atividade investigativa em ambiente escolar. De acordo com Sandoval (2005), a investigação geralmente refere-se a um processo de fazer perguntas, levantar hipóteses, buscar estratégias para investigá-las, gerar, analisar e interpretar dados, tirar conclusões, aplicar as conclusões à pergunta inicial e talvez, levantar novas perguntas. Nessa perspectiva, o desenvolvimento de procedimentos ultrapassa a mera execução de determinadas tarefas, tornando-se oportunidades para novas compreensões, significados e conhecimentos acerca do conteúdo ensinado.

$\mathrm{Na}$ Educação Infantil, os experimentos permitem explorar alguns aspectos de uma investigação como proposição de hipóteses, observação, registro, discussão e argumentação, além de leitura de imagens e representação com desenhos. Nesse sentido, o experimento investigativo se configura como estratégia para promover um contato, tanto com o observável quanto com a organização das ideias, no sentido de busca de soluções. Para Carvalho et al. (1998) e Kamii e Devries (1985), as etapas dessas atividades envolvem: agir sobre os objetos para ver como eles reagem; agir sobre os objetos para produzir o efeito desejado; tomar consciência de como se produziu o efeito desejado; criar explicação sobre as causas; comunicar o observado. Nessa direção, Lima, e Santos (2013) nos chamam a atenção de que, para o trabalho com crianças pequenas, a comunicação ou registro pode ser feito oralmente ou por meio de desenho, incorporando termos científicos de forma espontânea.

Em uma discussão mais ampla, Munford e Lima (2007) destacam que as atividades investigativas não são restritas às atividades de caráter experimental. Podemos propor que estudantes investiguem consultando livros e periódicos, conversando com especialistas ou outros, analisando dados já existentes e disponibilizados para consulta. Em outro trabalho, Sá (2009) aponta que, independente do tipo de atividade, não existe um roteiro que contenha todos os traços importantes de uma atividade investigativa. Assim, um roteiro pode explorar vários dos processos mobilizados durante uma 
investigação, ou pode explorar apenas um. Além disso, essa mesma autora ressalta que um aspecto importante que permite que uma dada experiência educacional possa se configurar como ensino por investigação é o ambiente de ensino aprendizagem, e não as atividades em si mesmas.

De acordo com Carvalho et al. (1998), uma atividade investigativa não pode se resumir a promover aprendizagem de um conceito específico, uma mera observação ou a simples manipulação de dados. Este tipo de atividade deve levar o aluno a refletir, discutir, explicar e relatar seu trabalho aos colegas. Assim, as atividades concebidas em uma perspectiva investigativa demandam do aluno um esforço interpretativo e (re) interpretativo que perpassa toda a atividade. Os estudantes realizam as ações tendo em vista sua audiência e as representações que eles possuem de como essa audiência interpretará os resultados e as conclusões da investigação.

No ensino de Ciências por investigação, as crianças interagem, exploram e experimentam o mundo natural, mas sem serem abandonados à própria sorte, nem ficarem restritas a uma manipulação puramente lúdica. Entretanto, por meio de atividades dessa natureza, as crianças são envolvidas em processos investigativos que permitem que elas se comprometam com a própria aprendizagem, desenvolvam novas compreensões e conhecimentos do conteúdo que está sendo trabalhado (Lima, e Maués, 2006).

Nessa perspectiva, promover uma Educação em Ciências que crie oportunidades para a criança expressar seus pensamentos, levantar questões e explicar o mundo depende do papel que a professora desempenha na sala de aula enquanto mediadora da aprendizagem e de vários fatores concomitantes. Sá, Lima e Aguiar (2011) enfatizam que:

para o ensino por investigação se concretizar é necessário um conjunto de elementos articulados espaço-temporalmente, isto é, ao mesmo tempo em que o professor tenha uma atitude favorável, os estudantes se sentirem curiosos e instigados a sanar suas curiosidades, indo eles mesmos atrás da solução do problema, do material didático ser instigador e das circunstâncias em que a atividade ocorre, como o momento do curso, o espaço físico, a disponibilidade e acesso aos recursos necessários, entre outros (Sá, Lima, \& Aguiar, 2011, p. 95).

Assim, ao promover a Educação em Ciências em uma perspectiva investigativa, a professora deve ser uma companheira de viagem, mais experiente nos caminhos, na leitura dos mapas, no registro e na sistematização da experiência vivida (Lima, \& Maués, 2006).

\section{Processo de Construção dos Dados}

Antes de apresentarmos o percurso metodológico percorrido para responder nossas questões, apresentamos os critérios para a escolha dos sujeitos e do ambiente no qual a pesquisa foi desenvolvida.

A seleção da escola ocorreu pela facilidade de realização da pesquisa. Trata-se 
de uma escola pública municipal que tem um investimento na formação continuada de seus profissionais e reconhece as crianças como sujeitos de direitos, incluindo, portanto, o direito a uma educação de qualidade. A escola atende crianças da faixa etária de 2 a 5 anos.

$\mathrm{Na}$ escola, buscamos uma professora da Educação Infantil não iniciante, que tivesse interesse e disponibilidade para construir conjuntamente formas de trabalho e para refletir sobre sua prática pedagógica ao abordar temas das ciências da natureza. Assim, chegamos à professora, a qual denominamos pelo nome fictício de Amanda.

Os dados desta pesquisa foram construídos a partir de observação participante, ao longo de oito meses. Ao todo, a turma era composta por 20 alunos, sendo 5 meninas e 15 meninos de quatro anos de idade. Na escola, essa turma era denominada como Turma Colorida. Para as crianças também foram atribuídos nomes fictícios visando garantir o sigilo necessário para assegurar a privacidade de todos. No percurso da investigação, foram realizados vários encontros entre a professora e a pesquisadora, para planejamento, avaliação e reflexão acerca das atividades vivenciadas pela turma. Além disso, foram realizadas diversas entrevistas narrativas e conversas com a professora e analisados os relatórios e demais registros produzidos por ela, bem como as produções das crianças em diferentes formas de registro, o caderno de campo da pesquisadora e imagens das crianças desenvolvendo as atividades propostas. As diferentes fontes de dados não foram usadas com o intuito de triangulação de dados como recomendam alguns autores (Erikson, 1989; Ludke, \& André, 1986). Nesta pesquisa, a diversidade de dados foi usada como complementação de sentidos e de deslocamentos gerados na busca de produção de significados do processo que estava sendo vivenciando. Além disso, buscamos dar legitimidade à pesquisa pela coerência entre o referencial teórico adotado, o modo de colocar o problema de pesquisa, o modo de construir as categorias de análise a partir das narrativas.

As entrevistas e conversas foram gravadas, ouvidas, transcritas, lidas individualmente ou em conjunto pelos pesquisadores. Os textos transcritos foram apresentados à professora para que ela pudesse fazer correções e complementações, uma vez que discurso oral carrega características diferentes do discurso escrito. Essas características podem, em alguns casos comprometer a intenção do que se queria dizer.

As entrevistas não se reduziram a perguntas e respostas previamente preparadas. Elas foram concebidas como uma produção de linguagem, onde sentidos foram criados na interlocução e estavam diretamente relacionadas às situações experienciadas pela professora e pesquisadora (Freitas, 2002). Foram valorizadas nesse processo, as falas da professora, por acreditarmos que há uma predisposição humana para a organização das próprias experiências em forma de narrativa.

Para Bakhtin (1997), o objeto de interesse das ciências humanas é o texto, que também pode ser compreendido como discurso. O discurso seja ele oral ou escrito, é produzido por pessoas que têm histórias distintas e trazem marcas culturais diversas. Para Bakhtin, 
a linguagem como uma criação coletiva, integrante de um diálogo cumulativo entre o "eu" e o "outro", entre muitos "eus" e muitos "outros". A linguagem é compreendida a partir de sua natureza sócio-histórica, ou seja, as palavras são tecidas a partir de uma multidão de fios ideológicos e servem de trama a todas as relações sociais em todos os domínios (Bakhtin, 1997, p. 41).

Para análise dos dados, partimos da ideia de que os saberes docentes são construídos, utilizados e partilhados em função dos contextos de trabalho e de que é apenas por meio de tais contextos que esses saberes fazem sentido. Assim, consideramos que a ação e o pensamento da professora carregam as marcas dos contextos nos quais se inserem. Podemos dizer que o saber docente não está no sujeito, e sim na relação entre o sujeito e o contexto (Therrien, \& Loiola, 2001). Portanto, apesar do foco de nossa análise ser a professora, só podemos abordar suas transformações tendo em vista os sujeitos com os quais ela interage na prática social concreta da sala de aula.

Antes de iniciarmos a coleta de dados por meio da observação participante e entrevistas, submetemos e tivemos nosso projeto aprovado pelo Comitê de Ética na Pesquisa da Instituição de Ensino Superior à qual a pesquisadora principal está vinculada. Atendendo aos preceitos da ética na pesquisa com seres humanos, redigimos um termo de consentimento livre e esclarecido que foi devidamente apresentado e autorizado por aqueles que participaram das gravações e/ou seus responsáveis.

Ao longo dos oito meses da pesquisa, Amanda desenvolveu várias atividades de ciências com as crianças da turma Colorida. No início de nossas observações a professora estava desenvolvendo atividades de autocuidado, higiene e saúde usando como estratégias vídeo, apresentação teatral, desenhos. A partir delas, passaram a discutir sobre microrganismos, em atividades denominadas inicialmente na turma de "mundo invisível" e durante o ano várias atividades relativas ao tema foram realizadas, porém não serão objeto de nossa análise neste artigo.

No período de junho a dezembro, a professora começou a desenvolver um projeto de experimentos com a turma Colorida. Como parte desse projeto, a professora trouxe uma boneca de pano que foi batizada pelas crianças com o nome de Cientista Sidméia. A Cientista possuía uma maleta com artefatos tais como lupa, caneta, bloco de notas, frascos, para serem explorados pelas crianças de forma lúdica em casa. Além disso, Sidméia também tinha um caderno de experimentos contendo 23 propostas de atividades. A cada semana, uma criança levava para casa a cientista Sidméia, sua maleta com materiais de trabalho e o caderno de experimentos para escolher um deles, realizar com a família e posteriormente apresentar em sala para os colegas.

Dentro do contexto dos experimentos, entre os meses de agosto e setembro, Amanda e a turma Colorida se envolveram em um projeto de atividades investigativas que culminou com apresentação dos trabalhos na feira de cultura da escola. Esse projeto foi deflagrado pela leitura de um livro de literatura infantil "O Mundinho" de Ingrid Biesemeyer Bellinghausen. A partir dessa leitura, as crianças se engajaram no planejamento e execução de invenções para solucionar problemas socioambientais. 
Além disso, visitaram a exposição de trabalhos de alunos do ensino fundamental e médio em uma feira de ciências do estado de Minas Gerais e também um laboratório de ciências de uma escola municipal.

Ao longo de todo esse período, Amanda fez várias reflexões e ressignificações de sua prática pedagógica a partir de discussões com a pesquisadora. $\mathrm{Na}$ próxima seção, apresentamos uma análise mais detalhada dos deslocamentos vivenciados pela professora e da construção de uma postura investigativa na turma Colorida a partir da sequência de atividades experimentais.

\section{Deslocamentos vivenciados pela professora ao desenvolver experimentos com as crianças}

Antes do início da pesquisa, Amanda já havia iniciado um trabalho compartilhado discutindo os seres "invisíveis", os microorganismos. As crianças vinham interagindo com materiais e procedimentos de observação, registro por desenhos, rodas de ciências. Nesse contexto, a proposta dos experimentos surgiu como mais uma possibilidade para um trabalho significativo e sistematizado com temas de ciências.

Para a realização das atividades experimentais, a cada semana, uma criança levava para casa a cientista Sidméia, sua maleta com materiais de trabalho e o caderno de experimentos (Figura 1).

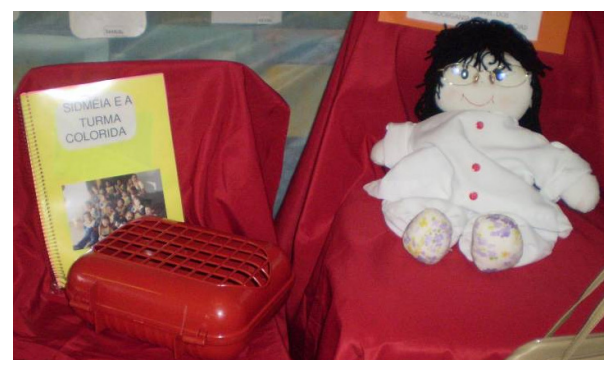

Figura 1. Sidméia, sua maleta e o caderno de experimento

Sidméia era uma boneca de pano, com pele clara, usava óculos e vestia um jaleco branco. A incorporação da Sidméia na rotina das atividades de ciências da turma demonstra a preocupação da professora em considerar aspectos relacionados às outras dimensões da experiência humana, muito importantes na infância, como a ludicidade e a imaginação.

Além disso, nesse caso, a inserção da boneca envolvia não só o trabalho com experimentos, mas também trazia à cena a representação da figura da cientista, rompendo um aspecto do estereótipo que compõe a imagem do cientista fortemente vinculado à figura masculina. A boneca representava uma cientista mulher. Contudo, Sidméia ainda trazia outros aspectos estereotipados da imagem do cientista como os óculos, o jaleco branco, a pele branca e a maleta de materiais. Aqui cabe ressaltar que inicialmente a professora e a pesquisadora haviam discutido a possibilidade de trazer uma boneca cientista que rompesse com a visão de senso comum sobre o cientista. A 
ideia era uma boneca que representasse uma mulher de pele negra mas, que ao mesmo tempo, mantivesse outros aspectos que as crianças associassem rapidamente com a imagem de cientistas, como o jaleco e o óculos. Contudo, a professora não conseguiu uma boneca com essas características em tempo hábil. Ao longo do projeto, as crianças tiveram contato com pesquisadores como uma cientista social e uma pedagoga para ajudar na desconstrução de um estereótipo de cientista.

O caderno de experimentos elaborado pela professora continha 23 roteiros de atividades retirados de livros diversos. De uma maneira geral, os roteiros das atividades forneciam os objetivos, os materiais, prescreviam o modo de fazer, resultados esperados ea explicação. As crianças e famílias deveriam seguir as instruções corretamente para chegar ao resultado esperado. A escolha dessas atividades representou o primeiro movimento da professora em direção ao desenvolvimento de experimentos com as crianças. Assim, foi natural que ela buscasse atividades tradicionais no Ensino de Ciências. Dentro dessa perspectiva, os roteiros dos experimentos propostos pela professora, inicialmente, não possuíam características investigativas. A Figura 2 apresenta a lista dos experimentos propostos, sendo que numeração não corresponde a ordem em que foram desenvolvidos.

1) Grudando balões na parede; 2) Mangueira que canta; 3) Telefone sem fio, 4) Oceano na garrafa, 5) Força da água; 6) Enchendo um balão com ar sem soprar; 7) Resistente e maleável; 8) Fogos de artifício no vidro; 9) Construindo um Estetoscópio; 10) Uvas passas saltitantes; 11) Tinta invisível, 12) Separando cores; 14) Órgão de garrafa; 15) Balões Malucos; 16) Fazendo um arco íris; 17) Voando alto; 18) Águas dançantes; 19) Força motriz; 20) Fazendo ovo flutuar; 21) Eletricidade estática; 22) Conhecendo a pressão atmosférica; 23) Bicarbonato de sódio e vinagre

Figura 2. Lista dos experimentos que compunham o caderno da Sidméia

Ao ser questionada acerca dos critérios utilizados para seleção dos experimentos para compor o caderno, Amanda disse:

Eu acho que a seleção tinha um objetivo de escolher aqueles experimentos que não demandavam tempo, que não demandavam muito material. Tinha também, um objetivo colado nesse que era a participação da família. Era chamar a família para a escola. Esse é um desafio até do projeto político pedagógico da escola. E é uma estratégia para trazer a família para escola. Então, se eu estou chamando a família eu tenho que estar pensando em determinados experimentos que fossem possíveis de serem feitos, que fossem cabíveis, que não fossem tão difíceis, com materiais que não fossem tão complicados de serem achados também.

A preocupação inicial da professora com a seleção dos experimentos era a viabilidade do desenvolvimento pelas famílias, considerando tanto o tempo, quanto o material e o nível de facilidade. Parece que o objetivo central de Amanda era trazer a família para dentro da escola. Ela não explicitou preocupação com o papel que o experimento iria desempenhar no trabalho com temas de ciências e no protagonismo das crianças. Contudo, a medida que as famílias e as crianças foram desenvolvendo os experimentos em sala, a professora começou a repensar os critérios utilizados incialmente para a seleção dos experimentos. Vejamos como ela reflete sobre isso. 
Eu estou sentindo um resultado bacana das famílias. (...) por outro lado, acho que eu teria que rever as minhas posturas. Porque não é só o professor escolher os experimentos, pronto, está escolhido. Eu fiz muito assim. Eu achei que eu ia resolver o problema [incorporar a família no projeto em curso], levei dez mil livros pra casa, passei a manhã de sábado inteirinha e a tarde também escolhendo quais experimentos que iam caber dentro dos meus objetivos. Mas e daí, eu não fiz mais nada com ele, no sentido de que eu tinha que saber qual experimento que o menino está levando pra casa pra saber, mas saber de verdade, pesquisar de verdade por que é que aquilo acontece daquele jeito. Eu senti que alguns experimentos eu sabia, mas sabia muito assim do cotidiano do que acontece.

Apesar dos roteiros das atividades experimentais propostos pela Amanda não terem sido concebidos como investigativos, o ambiente criado na sala de aula, a postura da professora ao conduzi-los, o envolvimento das crianças foram transformando-os em atividades investigativas.

\section{Gerenciamento do ambiente e postura da professora ao desenvolver os experimentos}

Nas aulas da professora Amanda, todos os experimentos foram desenvolvidos em rodas de conversas no espaço coletivo da sala de aula. Essa forma de organização se configura como uma metodologia participativa que proporciona a troca de ideias entre as crianças, o desenvolvimento da oralidade e da escuta, foco desse segmento de ensino. Nesse sentido, a roda de conversa se configura como:

[...] o momento privilegiado de diálogo e intercâmbio de ideias. Por meio desse exercício cotidiano as crianças podem ampliar suas capacidades comunicativas, como a fluência para falar, perguntar, expor suas ideias, dúvidas e descobertas, ampliar seu vocabulário e aprender a valorizar o grupo como instância de troca e aprendizagem. A participação na roda permite que as crianças aprendam a olhar e a ouvir os amigos, trocando experiências (MEC, 1998, v. 3, p. 138)

Nas rodas de conversas, antes de realizar os experimentos, os responsáveis pela atividade (uma criança e um membro de sua família) tinham que solicitar às crianças que falassem o que elas pensavam que iria acontecer e justificassem suas hipóteses. Em um caderno, a professora registrava as hipóteses e argumentos apresentados. Como exemplo, segue-se o registro de um experimento para discutir a pressão atmosférica, em que se enchia um copo com água, tampava a boca do copo com uma cartolina e o virava para baixo.

Experimento: Conhecendo um pouco sobre a pressão exercida pelo ar

Participantes: Érica e seu irmão David

O que aconteceu: Ao realizarem (David e Érica) tudo conforme o procedimento registrado nesse caderno, questionaram as crianças que estavam assistindo, sobre o que elas achavam que iria acontecer: o papel na borda do copo iria conseguir prender a água 
estando o copo de cabeça para baixo? Ambos cairiam imediatamente? À partir deste questionamento, as crianças não perderam tempo, foram logo trocando ideias, cada uma falando sobre seu ponto de vista.

“- O papel vai ficar todo molhado e água vai vazar ${ }^{1 ”}$ (Nicoly)

“- Eu também acho que a água vai vazar..” (Pedro Henrique)

O experimento deu certo. O papel conseguiu conter a água por um bom tempo, o que intrigou as crianças e provocou o levantamento de várias hipóteses sobre este acontecimento.

O Davi pediu que as crianças observasse bem a borda do copo e o que acontecia quando este era colocado de cabeça para baixo.

“- O papel fica preso, acho que a água prendeu o papel." (Luan)

“- Acho que apertou o papel e ele ficou preso." (Nicoly)

“- A água sobre e gruda no papel”. (Theo)

“- Não a água desce, gruda no papel e o papel fica grudado no copo.” (Arthur)

O Davi resolveu sem contar o segredo, dar uma forcinha. Pediu às crianças que observassem na superfície do copo. Chamou a atenção das mesmas para que percebessem que nesta superfície, existia ar, não teria como encher totalmente o copo. Ele questionou as crianças sobre o que acontecia quando virava rapidamente o copo prendendo sua borda com o papel. As crianças observavam que subiam bolhas e que essas bolhas eram de ar.

O Luan, começou a "matar a charada"

“- Muitas bolhas seguram o papel.” (Luan)

“- O ar da bolha que fica no copo, gruda o papel. As bolhas são ares! (Arthur)

Acho que essas crianças já estão realmente se transformando em pequenos cientistas!

Neste registro podemos perceber que os responsáveis instigaram as crianças a fazer previsões acerca do que ia acontecer, conforme combinado com a professora. As crianças fizeram previsões e, após a realização do experimento, formularam explicações para o acontecido. E para tentar ajudar as crianças a chegar à explicação plausível, o irmão de Érica chamou a atenção das crianças para algumas variáveis importantes, como a presença do ar no copo e repetiu o experimento de uma nova maneira.

Ao orientar a família a não dar a resposta de imediato, a solicitar que as crianças fizessem previsões, levantamento de hipóteses, a argumentarem, a professora teve uma postura investigativa. Acreditamos que o importante para ela era que as crianças se 
sentissem instigadas e se envolvessem com a atividade de forma mais ativa, engajada, expressando suas opiniões e buscando entender o ocorrido. Podemos inferir isso quando ela escreve em seu registro "O experimento deu certo" e ao finalizar o texto afirmando "Acho que as crianças já estão se transformando em verdadeiros cientistas!". Embora o roteiro fosse totalmente orientado, e não tivesse um problema inicial, a postura com que a atividade foi conduzida se configurou como um postura investigativa.

Ao realizar os experimentos, à medida em que foram entendendo a dinâmica das aulas com os experimentos, as crianças passaram a ganhar confiança e autonomia para fazer intervenções com mais protagonismo, a estabelecer relações com outras atividades já desenvolvidas e a valorizar mais o processo do que o produto. Vejamos como essa postura investigativa das crianças foi construída de maneira mais significativa nas interações da sala de aula na visão da professora.

O experimento "Fazendo o ovo flutuar" foi o escolhido por Nina e sua mãe. O objetivo dessa atividade era demonstrar que o ovo pode flutuar ou não, dependendo da mistura contida no meio em que está. Quando a aluna Nina e sua mãe inseriram o ovo na água, ele não flutuou. Então, a aluna Lara começou a propor novas situações para serem testadas dizendo: "Eu quero ver o que é que acontece se colocar primeiro o ovo". Nina e sua mãe seguiram a orientação da Lara e o resultado não se alterou. Sugeri dissolver outras "coisas" na água para ver se fazia diferença. Então, Nina acrescentou sal na água e o ovo flutuou. Lara novamente perguntou: "E se colocar açúcar no lugar do sal." Assim foi feito, e Lara continuou propondo alterações na atividade. As demais crianças acompanhavam atentamente os experimentos e passaram, também, a fazer sugestões. Nesse momento, as crianças começaram a perceber que elas podiam agir sobre os materiais, além do colega que estava realizando o experimento.

Lara, uma pequena menina de olhar atento, não se satisfez em ser apenas uma expectadora passiva na realização do experimento e queria saber mais: "e se..., "e se fizer assim”. Nessa atividade, ela desempenhou o papel de mediadora, levantando hipóteses e alterando variáveis no experimento. A medida em que falava, propunha uma nova situação a ser testada, levando os colegas a pensar sobre o que dizia e, consequentemente, trazendo novas interações discursivas na roda de conversa. Além disso, atraiu muitos olhares para ela, que vislumbravam novas possibilidades, algo diferente do que estava acontecendo até então. A partir desse momento, um acordo tácito que vinha se construindo no grupo ganha maior dimensão. As crianças percebiam, construíam o que contavam como experiência válida e significativa. Ao perceber a postura da Lara, a professora foi alimentando o interesse da menina oferecendo condições materiais e pedagógicas para que ela testasse suas hipóteses. Instalou-se ali uma zona de desenvolvimento proximal ${ }^{1}$ (Vygotsky, 2001) e a participação foi sendo ampliada. De acordo com Goulart e Roth (2010), as ações não só determinaram sua forma de participação como "expandiram o campo transformando-se numa nova prática no grupo".

1 Vygotsky (2001), em um dos conceitos centrais de sua teoria, apresenta o nível de desenvolvimento real, como aquilo que a criança consegue realizar sozinha; o nível de desenvolvimento proximal, representado por aquilo que a criança pode fazer pela mediação de parceiros mais experientes. 


\section{Reflexões da Professora acerca da sua prática e algumas mudanças}

Até o experimento da flutuação do ovo, Amanda ainda não tinha conseguido desenvolver com tanta fluidez a escuta ativa das crianças no que se refere aos temas das ciências. Mas nesta aula a professora acolheu a forma de participação conduzida por Lara, e a partir daí, transformou a dinâmica de suas aulas. As crianças passaram a intervir nos experimentos, a perguntar, propor alternativas para resolver as questões, propor alterações, discutir, se posicionar dentro do que era proposto. Os erros também passaram a contribuir para a construção da cultura de pensar e fazer a ciência da sala de aula da Educação Infantil na turma Colorida. E as crianças iam alterando seus modos de participação. Vejamos como a professora reflete sobre isso:

Apesar de alguns experimentos não darem certo durante nosso percurso e as crianças ficarem até frustradas em um momento inicial, aproveitamos disto para ouvir mais as crianças, levantar outras hipóteses, tentar formas alternativas e até mesmo pesquisar em outros locais. O erro também nos faz mudar de lugar!

Quando diz que as atividades "não deram certo" a professora considera o erro como parte de um processo de construção de conhecimentos e o traz como um elemento de deslocamento da zona de conforto dela e da turma Colorida. A escuta das crianças pela professora, que validou e fomentou atitudes diante dos experimentos, ampliou os modos de participação do grupo não só nas atividades que envolviam esse tema como também em relação a outras atividades de ciências que foram experienciadas durante $o$ ano. Mais uma vez, fica evidenciada a aproximação da professora à abordagem investigativa.

No decorrer dos outros experimentos, a postura das crianças em buscar experimentar modos diferentes do prescrito no roteiro foi cada vez mais se destacando. Elas passaram a estabelecer relações entre experimentos anteriores para buscar explicações para o que acontecia no momento. Criaram, assim, possibilidades de estabelecer relações entre a percepção do mundo e os fenômenos que só são percebidos se apresentados pelo Outro. Vejamos como Amanda rememora isso:

No experimento do ímã, aquele que o menino amarra um fio e puxa o clipes com o ímã. Os meninos já estão adotando uma postura assim: "e se a gente fizesse desse jeito? E se a gente fizesse do outro jeito?" Então duas coisas que eu estou notando na postura deles. Esse "e se" que a todo o momento está constante, de querer experimentar as coisas de outro jeito. Que eu acho (...) um conhecimento, um processo de trabalhar com experimentos que é a questão do pensar de formas diferentes. E outra coisa é de pegar algo de um experimento anterior. Por exemplo, a gente começou com magnetismo, já tinha mexido antes. E de fazer relação de um experimento com outro, para criar conceitos. Então assim, alguns, nesse dia do experimento do ímã, alguns já pensavam: "ah, tem cola, por isso que o ímã puxa". E outros pensavam: "não é cola. Lembra do outro experimento que a gente fez com o ímã que o ímã tem uma força que puxa?" Eles discutiam entre si sobre as hipóteses. E aquele que está no pensamento mais básico, eu acho que ele desenvolve com isso.

No decurso das atividades, escutando as crianças e organizando tempos, 
espaços e materiais, a professora se permitiu guiar pelas explorações das crianças. Seus relatos também revelam importância dada à regularidade, constância na realização de atividades com as crianças pequenas, competentes e que assumiam um protagonismo rico de significações.

Inicialmente, ao selecionar as atividades experimentais a serem realizadas com os alunos, dentre outros motivos, Amanda tinha como objetivo apresentar fenômenos que demonstravam fatos científicos. Com a rotina de desenvolver experimentos com as crianças, a professora começa a refletir acerca de alguns pontos importantes. Por exemplo,

Essa questão de pegar o que ele viu em um experimento e transferir para o outro. Isso vem acontecendo com muita constância também (...) a constância de estar fazendo o experimento, de ter isso como uma rotina da sala de aula. Eu acho que propicia isso, porque na hora que você coloca isso como uma prioridade, que você coloca isso como um projeto da sala, como uma prioridade da sala, você começa a fazer experimento com mais constância. E é a constância disso que começa a elaborar um tanto de hipóteses. Um tanto de pensamentos, um tanto de ligações entre um conhecimento e outro para formar outro conhecimento. Isso seria o pensamento que a gente tanto fala. Porque tem certas coisas que são imprevisíveis por mais que você tenta prever o que pode acontecer, tem que ter isso também, uma coisa que eu não fazia e comecei a fazer, mas tem coisas que são imprevisíveis. Que é importante trabalhar com esse imprevisível, mas você tem que ter suporte. (...) isso ajuda a gente. Na hora que você vai fazer na prática, como que muda a sua prática!

Assim, a professora refletiu sobre a práxis que transforma o modo de ensinar, o modo de aprender, o modo de participar. Nessa ação dinâmica e processual que vivenciou, de reflexão e formação ao aceitar o desafio de compartilhar um trabalho de ciências da natureza, ela reordenou metas e construiu sentidos com os participantes. Realmente, planejar e executar são ações diferentes, e lidar com a imprevisibilidade estava sendo, para ela, ao mesmo tempo sedutor e inquietante. Além do mais, o que vinha sendo construído em torno das ciências da natureza tinha tanto significado que passou a se tornar o eixo do trabalho na turma, e a professora começou a vencer um de seus desafios identificados inicialmente; o de lidar com as diferentes demandas da escola.

Algumas aprendizagens da docência, como estratégias didáticas e modos de ação só são possíveis de serem construídas na interação, preponderantemente, com os alunos, nas práticas sociais daquele grupo específico, sem desconsiderar as outras interações da professora com a pesquisa. As reflexões sobre essas práticas contribuem para organizar seu pensamento e sua atividade docente, trazendo a possibilidade de novas abordagens.

Com o desenvolvimento das atividades experimentais, a professora passou a dar cada vez mais centralidade aos procedimentos e a como os alunos vivenciavam esses processos. Em relação a isto, ela afirmou:

Outra coisa que eu estou percebendo que está acontecendo é como que eles estão 
se interessando muito mais pelo processo, pelo processo de acompanhamento do experimento do que pelo resultado em si. A mãe do Davi fez aquele experimento que chama "oceano na garrafa". Você coloca vinagre, coloca anilina e coloca óleo. E faz um oceano dentro da garrafa. Aí, ela trouxe o experimento, mas fez diferente de todo mundo que tem feito até então. Que lá no caderno da Sidméia vem explicado que não é para trazer experiência pronta, é pra fazer com as crianças. Mas ela trouxe pronta. Eu acho que ela não entendeu essa parte de que é importante fazer em sala. Ela trouxe pronto, mostrou para os meninos, contou o que acontecia, como é que foi, o que que ela usou. E os meninos começaram a ficar agitados, começaram a perguntar, "mas como que faz? Como que faz?" Por mais que ela falasse, toda hora, eles falavam: "mas como você fez?" Eu achei bacana, então a gente combinou que no dia seguinte, eu iria fazer com eles. Aí no dia seguinte, eu chamei o Davi, coloquei o Davi do meu lado: "Agora você vai contar pra gente, foi muito legal você ter trazido o experimento, mas agora você vai contar para os coleguinhas, como foi que você fez, o que você usou". Então, de antemão, eu já peguei, juntei todos os materiais necessários e ele foi falando. Então, ele se sentiu mais importante também. E aí os meninos acalmaram (...). A questão do processo está ganhando importância. Entendeu? Eles não ficaram passivos. Ah, levei o experimento pronto, deu nisso e eu fiz assim. Eles falaram, "como é que é? O que você fez? O que você misturou?". Eu achei muito legal. A gente tem o tempo da gente, eles tem o tempo deles. (...) E está com conteúdo, está bacana. Trabalhar com ciências faz a gente perceber de verdade como é que a apropriação do conhecimento pela criança se dá (...).

Novamente, evidencia-se o movimento de transformação da professora, de uma perspectiva de atividades experimentais mais demonstrativas de fenômenos de uma realidade objetiva, rumo a uma perspectiva mais investigativa, com um olhar atento a como os alunos interagem com estes conhecimentos. Além disso, possibilitando novos desafios ao validar os conhecimentos advindos das crianças, que são o foco do processo educativo.

Nesse sentido, percebe-se uma compreensão de aprendizagem de ciências na Educação Infantil como uma aproximação aos conhecimentos do mundo natural mediada pela investigação. Também se evidencia o olhar para a aprendizagem e desenvolvimento das crianças, o que mais uma vez nos remete a Vygotsky (1991) no que se refere à importância da interação social na construção das funções psicológicas, e, portanto, para a importância da qualidade da interação dos adultos com as crianças nas situações de aprendizagem. Tendo como referência a abordagem Vygotskiana, Oliveira (2000) nos diz que apenas por estarem as crianças imersas em ambientes informadores, não se dá necessariamente o desenvolvimento. É fundamental ao processo de desenvolvimento "a intervenção deliberada dos membros mais maduros da cultura" (Oliveira, 2000). Na turma foram criados espaços, tempos e artefatos que fizeram parte do ambiente informador, planejado e mediado pela professora Amanda.

O trabalho com os experimentos, além de nos indicar a compreensão de aprendizagem enquanto aproximação aos temas das ciências mediado pela investigação, também evidencia transformações nas visões da ciência presentes na prática de Amanda. Tais transformações foram identificadas em diferentes aspectos. Buscamos identificar 
paralelos entre a forma com que a professora organizou a atividade e a postura que foi assumindo ao desenvolver as atividades com as crianças.

No que se refere à forma como organizava as atividades, Amanda inicialmente tinha grande preocupação com a objetividade do conhecimento científico, na qual se pautou ao planejar como seria o trabalho com experimentos naquela turma. A professora organizou as atividades de experimentos como algo que poderia ser executado seguindose instruções pré-estabelecidas, sendo até mesmo alternativas pré-estabelecidas.

Cada experimento, se realizado de forma adequada, supostamente levaria a um resultado correto com uma única explicação. É evidente a ideia de uma "receita". Os alunos deveriam fazer os experimentos em casa e depois demonstrar sua execução em sala de aula. Essa abordagem é identificada na literatura do campo da Educação em Ciências como uma visão rígida, exata, sobre a investigação, em que se observa a utilização de um "método científico" como "uma sequência de etapas definidas, destacando o rigor do mesmo e o caráter exato dos dados obtidos" (Gil-Perez et al., 2001, p. 130).

Ao ampliar sua escuta e validar a ação do grupo, possibilitando que na roda as crianças interferissem nas instruções dos experimentos, a professora começou a investir em variáveis propostas pelas crianças, o que revela outro jeito de pensar e mediar aquelas atividades, que foram se tornando cada vez mais investigativas e mais partilhadas no grupo. Assim, correu um deslocamento da valorização do produto como uma confirmação do resultado pretendido, para a valorização do processo, por caminhos indicados pelas crianças, envolvendo a curiosidade, o questionamento, a imaginação, as respostas, a manipulação de materiais, que passaram a conduzir o grupo a uma postura investigativa. Desse modo, é como se o movimento do grupo "rompesse" com a tradição da ciência elitista e simplista da evolução dos conhecimentos científicos, ampliando o protagonismo das crianças.

Partindo de suas reflexões, e paralelamente ao desenvolvimento dos experimentos, no segundo semestre letivo, Amanda decidiu envolver a turma em um projeto para ser apresentado na feira de cultura da escola. Nesse sentido, ela assumiu a perspectiva investigativa como orientadora do projeto das crianças.

\section{Planejamento e desenvolvimento de atividades investigativas}

Para o desenvolvimento do projeto da feira de cultura, Amanda planejou envolver as crianças na construção de invenções, mas de uma maneira investigativa. Ela usou da literatura infantil para criar uma situação problema e envolver as crianças em discussões sobre a temática socioambiental e, assim, construir questões para serem investigadas, levantar hipóteses, planejar as ações, desenvolver os planos de ações e comunicar publicamente os resultados. A Figura 3 apresenta, de forma sucinta, as características investigativas das atividades, as ações da professora e das crianças durante o desenvolvimento do projeto. 


\begin{tabular}{|c|c|c|}
\hline $\begin{array}{l}\text { Características } \\
\text { Investigativas }\end{array}$ & Ação da professora & Ação das crianças \\
\hline Sensibilização & $\begin{array}{l}\text { Ler o livro infantil "O Mundinho", para iniciar } \\
\text { as conversas nas rodas. As conversas giraram } \\
\text { sobre os problemas do nosso mundo, da nossa } \\
\text { cidade, rua e casa. }\end{array}$ & $\begin{array}{l}\text { Registrar das impressões do livro, seus } \\
\text { problemas e impactos da ação humana, } \\
\text { por meio de desenhos. }\end{array}$ \\
\hline $\begin{array}{l}\text { Construção de um } \\
\text { problema }\end{array}$ & $\begin{array}{l}\text { Propor um dever de casa em que as crianças, } \\
\text { junto com suas famílias, deveriam levantar } \\
\text { problemas socioambientais que enfrentam em } \\
\text { seu bairro, sua cidade e no país. } \\
\text { Selecionar junto com as crianças os problemas } \\
\text { a serem investigados. }\end{array}$ & $\begin{array}{l}\text { Apresentar os problemas } \\
\text { socioambientais levantados junto às } \\
\text { famílias. }\end{array}$ \\
\hline $\begin{array}{l}\text { Levantamento de } \\
\text { hipóteses }\end{array}$ & $\begin{array}{l}\text { Discutir os problemas com o foco no "fazer" do } \\
\text { cientista e das ciências. }\end{array}$ & $\begin{array}{l}\text { Propor a criação de máquinas } \\
\text { para solucionar os problemas } \\
\text { socioambientais construídos pela } \\
\text { turma. }\end{array}$ \\
\hline $\begin{array}{l}\text { Planejamento das } \\
\text { ações }\end{array}$ & $\begin{array}{l}\text { Apresentar às crianças um conjunto de } \\
\text { materiais diversos (sucatas) como restos } \\
\text { de brinquedos, caixas de leite, mangueiras, } \\
\text { chuveiro, etc. para subsidiar o planejamento } \\
\text { dos protótipos. }\end{array}$ & \begin{tabular}{|l} 
Separar os materiais para serem \\
utilizados na construção dos \\
protótipos. Planejar os protótipos e \\
apresentar o planejamento por meio de \\
desenhos. \\
\end{tabular} \\
\hline $\begin{array}{l}\text { Construção das } \\
\text { invenções }\end{array}$ & $\begin{array}{l}\text { Orientar e assistir os grupos na construção dos } \\
\text { protótipos. }\end{array}$ & $\begin{array}{l}\text { Construir os protótipos de acordo com } \\
\text { o planejamento. }\end{array}$ \\
\hline $\begin{array}{l}\text { Comunicação } \\
\text { pública dos } \\
\text { resultados }\end{array}$ & $\begin{array}{l}\text { Organizar a apresentação das crianças na Feira } \\
\text { de Cultura da escola. Construir um registro do } \\
\text { processo vivenciado. }\end{array}$ & $\begin{array}{l}\text { Apresentar os protótipos e o processo } \\
\text { de construção para os pais e outras } \\
\text { crianças da escola. }\end{array}$ \\
\hline
\end{tabular}

Figura 3. Características investigativas das atividades e ações da professora e das crianças

$\mathrm{Na}$ fase de sensibilização, a professora realizou a leitura do livro infantil $O$ Mundinho, que foi um importante disparador das conversas nas rodas. As conversas giraram sobre os problemas do nosso mundo, da nossa cidade, rua e casa. A professora solicitou que as crianças fizessem o registro das impressões do livro, seus problemas e impactos da ação humana, por meio de desenhos. Além disso, ela organizou também algumas atividades para serem feitas em casa, na qual solicitava que as crianças, junto com suas famílias, levantassem problemas que enfrentam em seu bairro, sua cidade e no país. Vejamos como a professora discorre sobre essa etapa:

Para desenvolver as atividades, conversamos sobre os problemas do nosso mundo, do planeta Terra, da nossa cidade, da rua, da casa. Para isso, utilizamos reportagens, pesquisas sobre estas leituras de livros (literatura infantil) sobre o tema, conversas e mais conversas durante as rodinhas. Também não deixamos de conversar sobre nossas posturas e responsabilidades relacionadas a esses problemas (o que podemos fazer para evitar desperdícios de água, papel, material escolar, como tentar resolver problemas com os colegas sem usar de força física, etc.). Este tema foi muito importante para conversarmos sobre questões ligadas à ética, à preservação do ambiente onde vivemos e nossas responsabilidades de criar um ambiente de boa convivência.

Tamir (1990) afirma que, ao propor uma atividade de investigação na escola, a 
professora deve discutir junto aos estudantes a importância do tema em estudo. Uma orientação investigativa pressupõe o envolvimento dos estudantes em uma tarefa cuja finalidade e sentido estejam claros para eles. A discussão da importância do tema proposto contribui para que os estudantes comecem a formar uma compreensão preliminar da situação problemática, permitindo, assim, a realização de uma análise qualitativa dessa situação, que lhes ajude a considerá-la sob a ótica de um problema preciso.

$\mathrm{Na}$ fase da construção de problemas, Amanda envolveu a turma em várias conversas e atividades para mobilizar as crianças em relação às questões socioambientais que enfrentamos em nossa vida cotidiana. Partindo dessas questões, a professora e as crianças conseguiram chegar a quatro problemas: 1) Como contribuir para diminuir o desmatamento e a extinção de florestas? 2) Como contribuir para resolver o problema da poluição do ar? 3) Como resolver o problema da poluição dos rios? 4) Como ajudar a aliviar o sofrimento de alguns animais e não deixar que aconteça o mesmo que aconteceu com o cachorro da Kely, que acabou morrendo de tantas picadas de carrapato? Vejamos como a professora rememora esse momento:

A gente tinha conversado sobre o que o cientista faz: cria coisas para ajudar o mundo, ajudar as pessoas e a gente tinha então que pensar nos problemas para depois pensar em como fazer para resolver esses problemas, enquanto cientistas. Depois de conversarmos bastante sobre os problemas, tentamos solucioná-los inventando máquinas para isso. Lembrar do papel do cientista em nossa sociedade nos remeteu à construção das máquinas. Surgiram quatro máquinas: máquina de jogar sementinha (para resolver o problema do desmatamento e extinção de florestas), máquina de tirar fumaça do mundo (para resolver o problema da poluição do ar), robô de tirar água do rio (para resolver o problema da poluição dos rios), robô de matar carrapato (aliviar o sofrimento de alguns animais e não deixar que aconteça o mesmo que aconteceu com o cachorro da Kely, que acabou morrendo de tantas picadas de carrapato - isso chocou demais as crianças).

As fases de levantamento de hipóteses e planejamento das ações aconteceram simultaneamente. A professora ofereceu materiais diversificados às crianças: chuveiro estragado, sucatas, caixas de diferentes tamanhos e modelos, teclados de computadores, rodinhas de carrinhos, tampas, dentre outros. As crianças foram organizadas em grupos para planejar estratégias visando solucioná-los. Cada grupo discutiu como seria a invenção e todos registraram o consenso por meio de desenhos. Na Figura 4, apresentamos dois exemplos desses planejamentos. Nesses desenhos, os registros foram adicionados por Amanda, a partir das explicações das crianças. 
ROB.̂. DE LIMPAR ÁEUA DO RIO

A

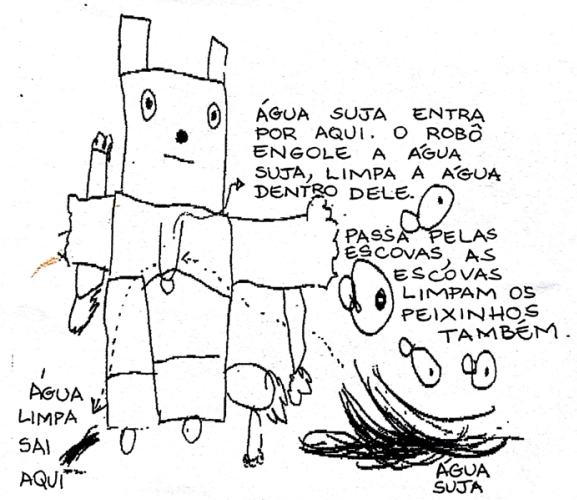

ROBÔ DE MATAR CARRAPATOS B

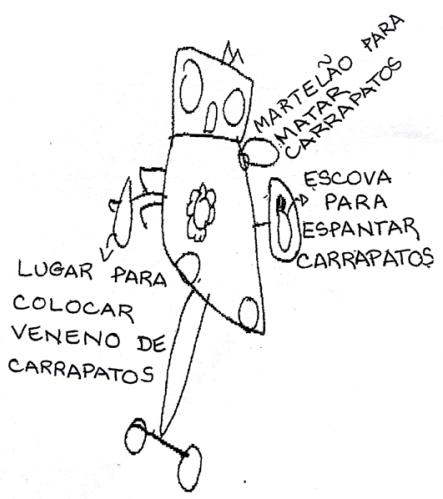

Figura 4. Planejamento dos Protótipos: A) Robô de limpar água do rio B) Robô de matar carrapato

Na Educação Infantil, o desenho é uma forma que a criança utiliza para se comunicar. Por meio do desenho a professora pode compreender o amadurecimento e os avanços da criança no processo de construção do conhecimento. De acordo com Derdyk (1994),

o desenho também é manifestação da inteligência. A criança vive a inventar explicações, hipóteses e teorias para compreender a realidade. O mundo para a criança é continuamente reinventado. Ela constrói suas hipóteses e desenvolve sua capacidade intelectual e projetiva, principalmente quando existem possibilidades e condições físicas, emocionais e intelectuais para elaborar estas "teorias" sob forma de atividades expressivas (Derdyk, 1994, p. 54).

$\mathrm{Na}$ fase da construção dos protótipos, cada grupo, com a ajuda da professora e da pesquisadora, executou o planejamento proposto.

Para a fase de comunicação pública dos resultados foi criado um ambiente no qual a turma Colorida expôs seu processo de trabalho, comunicando seus procedimentos e aprendizagens aos visitantes da Feira de Cultura da escola. Os desenhos foram ampliados para compor um dos painéis da mostra da turma, na qual foram apresentados exclusivamente os trabalhos de ciências realizados durante o ano, sob o título: "Cientistas desde sempre". Os protótipos criados ficaram expostos, bem como os registros da professora acerca do processo de desenvolvimento das atividades pelos grupos. As crianças apresentaram os protótipos e falaram sobre o processo de construção das “invenções” para os pais e outras crianças da escola.

Carvalho et al. (2004) dizem que uma atividade investigativa deve levar o aluno a refletir, discutir, explicar e relatar seu trabalho aos colegas. Nesse sentido, elas demandam do aluno um esforço interpretativo que perpassa toda a atividade e inclui a elaboração do problema, o planejamento das ações, as observações, o registro e o tratamento dos dados. Os estudantes realizam essas ações tendo em vista sua audiência 
e as representações que eles possuem de como essa audiência interpretará os resultados e as conclusões da investigação.

\section{Discussão}

Ao realizar essa sequência de atividades de ciências de forma lúdica, ancorada em metodologias da Educação Infantil, a professora trouxe para a sala de aula uma perspectiva mais aberta e mais inovadora de ciências. Amanda criou estratégias didáticas voltadas às ciências, envolvendo o brincar. A ciência estava presente como elemento da brincadeira para as crianças, como suporte à tarefa de serem cientistas inventores. Desse modo, a ciência contribuiu na brincadeira e a brincadeira ajudou as crianças a aprender a pensar as ciências e lidar com seus procedimentos. A professora alimentou o brincar de ser cientista com certas informações e recursos materiais.

Em nossa análise da prática de Amanda, destacam-se dois aspectos importantes sobre as visões de ciência presentes naquela sala de aula. Primeiro, para brincar de serem inventores, as crianças precisavam discutir os problemas socioambientais. Ao criarem os modelos, mesmo estes não funcionando, as crianças, em sua representação de cientistas, de ciência, de inventores, buscaram responder a problemas socioambientais. Tais problemas não foram introduzidos de forma descontextualizada: eram problemas próximos de suas vivências enquanto sujeitos sociais de tenra idade. Estas são questões que estão hoje em consonância com o desafio de educar na perspectiva de uma sociedade sustentável, de promover uma educação que possibilite às crianças uma visão adequada dos problemas da sociedade, suas causas e possíveis soluções.

Além disso, para "serem" cientistas, as crianças precisaram saber quem é o cientista, o que ele faz. Estava em cena uma perspectiva de ciência que é construída em grupo, partilhada, planejada, analisada, em contraposição a uma visão individualista e elitista da ciência amplamente verificada na literatura (Hodson, 1992; Gil-Perez et al, 2001).

A professora alimentou a brincadeira e a imaginação com conhecimentos sobre os procedimentos de cientista, definindo-os, na prática, como: discutir, observar, desenhar e escrever registrando as informações, trabalhar em grupo, planejar, comparar, selecionar materiais, construir equipamentos, comunicar os resultados.

Ao propor a realização do trabalho com os inventos, Amanda trouxe o fazer científico hipotético, trabalhando com uma das relações da ciência de produzir conhecimentos e tecnologia para a sociedade, para resolver problemas sociais, por meio de uma estratégia peculiar e fundamental na Educação Infantil: o brincar, a ludicidade.

O brincar, a linguagem infantil por excelência, principal modo de expressão da infância é uma atividade imaginativa que contribui para que as crianças deem sentidos próprios ao mundo. Em diálogo com a teoria de Vygotsky (1991), é possível afirmar que a situação imaginária vivenciada pelas crianças da Educação Infantil tem estreita relação com a realidade, e traz as marcas da experiência social das crianças, de suas vivências e seus conhecimentos quanto à realidade. $\mathrm{O}$ brincar é uma linguagem por meio da qual 
as crianças se organizam, inventam, criam papéis, representam, criam nova realidade e novos contextos.

Retomando as situações vivenciadas pela turma Colorida e sua professora em relação aos temas de ciências, uma boneca cientista, a Sidméia, chegou à turma e começou a partilhar com eles o que vinham descobrindo. Do "alto" de seus 4 anos de idade, as crianças incorporaram a presença da Sidméia nas atividades, como um membro daquela comunidade. Ela participava de brincadeiras, não no papel de boneca, mas no papel de Sidméia, a Cientista.

No caso dos experimentos, partilhar a curiosidade, a partir da observação direta do fenômeno representado, apresentado pelo colega, instigava a imaginação, provocava interações cada vez mais dialogadas e problematizadas na medida em que as crianças vivenciavam esse fazer ciências.

Na situação do "Mundinho", ao brincarem de ser inventores, as crianças buscavam atender ao que seu imaginário, suas representações, seu pensamento demandavam. Era o brinquedo permeando a atitude da criança frente à realidade, conforme nos diz Vygotsky (1991). Assim, a forma de abordagem da temática que gerou as invenções foi ao encontro da visão de saber sobre ciências no campo do Ensino de Ciências.

Os movimentos ocorridos no trabalho da professora podem ser (ou foram) interpretados a partir de várias manifestações, dentre elas: seu discurso quanto ao que percebeu nas aprendizagens das crianças e nas suas próprias aprendizagens, e o que enunciou quanto aos planejamentos e resultados. Uma grande transformação, que se refere tanto ao primeiro movimento relatado sobre a vivência com os experimentos, ao instaurar com as crianças um clima investigativo, quanto ao processo de discussão de problemas socioambientais que deram origem aos inventos, é a centralidade que as atividades de ciências passam a ter na vida do grupo, observada no decorrer de seu trabalho. Nesse sentido, Amanda assumiu o lugar de professora que ensina ciências, reconhecendo que é possível ensinar ciências aos pequenos e como se pode fazê-lo. Parece-nos que ela compreendeu que ensinar ciências exige mais do que saber ciências, embora, como nos diz Amanda, "o conhecimento da professora abre portas", referindose aos conhecimentos específicos, disciplinares sobre ciências da natureza.

A sala de aula onde a professora se preocupava sobre como articular tantas demandas das diferentes áreas e da proposta global da escola, o que no início de nossa parceria lhe causava grande ansiedade, agora estava impregnada de ciências da natureza e suas representações. As ciências da natureza se tornaram o eixo de trabalho daquela turma, articuladas a outras áreas do conhecimento, como propõem as teorias e currículos da Educação Infantil (Kramer, 1996; Faria, \& Dias, 2008; Melo, 2015).

\section{Considerações Finais}

Neste artigo, nos propusemos a narrar e analisar como uma professora da Educação Infantil foi se aproximando de uma abordagem investigativa do ensino de ciências. Nessa direção, levantamos duas questões: Como as atividades propostas pela 
professora foram se aproximando de uma perspectiva investigativa? Que deslocamentos de sentidos ocorrem na maneira como a professora compreende o ensino de ciências, ao longo de seu trabalho com as crianças?

Para responde-las, começamos apresentando e caracterizando um conjunto de atividades experimentais que a professora selecionou e propôs para ser desenvolvido pelas crianças em parceria com as famílias. Inicialmente, constatamos que os roteiros das atividades não apresentavam características investigativas. Eles continham objetivos que explicitavam o que deveria acontecer, os materiais necessários, os procedimentos a serem seguidos, os resultados esperados e as explicações dos fenômenos. No entanto, à medida em que as atividades aconteciam, a professora foi modificando sua interação com turma e com o objeto de conhecimento na busca de um maior protagonismo e engajamento das crianças. Com isso, ela passou a problematizar as atividades, levantar questões para as quais as crianças não tinham respostas imediatas, considerar novas situações problemas propostas pelos alunos, valorizar a observação, o levantamento de hipóteses, o debate, a argumentação e a construção de explicações. Dessa forma, Amanda foi se deslocando de uma postura mais tradicional do ensino de ciências, que considera a atividade experimental como um conjunto de passos que devem ser seguidos, em direção a uma postura mais próxima de uma perspectiva investigativa. Esses deslocamentos vivenciados durante a realização das atividades experimentais levaram a professora a propor, no segundo momento, o desenvolvimento de atividades com características investigativas mais evidentes.

Os movimentos da professora nas duas situações (realização de experimentos e construções de protótipos) não apontam para um resultado de transformação linear. Ao contrário, observamos a coexistência de visões de ciência, inerentes a momentos de desenvolvimento.

Podemos inferir que quando a professora partiu de sua memória escolar acerca do ensino de ciências, ela propôs um conjunto de atividades experimentais tradicionais a partir de uma visão de ciências como conjunto de conhecimentos prontos e acabados, construídos por meio de fatos e leis em uma perspectiva empirista. Quando se baseou em suas práticas oriundas das metodologias da Educação Infantil, ela propôs atividades permeadas pela visão de ciências como desenvolvimento de teorias para melhorar o entendimento e a ação sobre o mundo. Dessa forma, ela passou a vislumbrar que esse ensino não precisa ser tão diferente dos demais, de modo que o caminho foi se mostrando cada vez mais promissor nessa perspectiva.

Na discussão do campo da formação de professoras, esse resultado pode prestar contribuição ao debate, no sentido de referendar a importância da presença de um parceiro mais experiente que ajude a professora a pensar mais e partilhar, refletir, escutar. No movimento de debater e refletir, pensar junto sobre o que fazer, o espaço de reflexão deve ser mais valorizado nas propostas de formação de professoras. A reflexão é um modo de se colocar diante dos desafios cotidianos da condição de professoras, uma maneira de se encarar, de se posicionar e responder às demandas. Assim, não basta que 
sejam oferecidos cursos sobre ensino de ciências para as professoras, mas é necessário investir em condições de reflexão mais amplas e constantes sobre a prática docente, na medida em que ela acontece. A formação continuada de professoras, demanda uma vinculação direta com sua prática pedagógica cotidiana. Os pares, que vivem processos formativos semelhantes, podem fomentar espaços de discussão coletiva acerca de suas práticas no interior da escola. Os achados desta pesquisa apontam para a necessidade de investigar as mudanças que esses trabalhos produzem no cotidiano escolar.

Muitas vezes, especialistas da área de Educação em Ciências pensam processos formativos a partir do ensino de conteúdos disciplinares das ciências da natureza, como forma de instrumentalizar as professoras. As professoras também demandam isso. Não negamos aqui a importância de que as professoras da Educação Infantil busquem se apropriar de conhecimentos desta área para enriquecer suas práticas, como deve acontecer, também, em relação aos demais campos de conhecimento. Os saberes das ciências compõem um conjunto de saberes socialmente valorizados, e portanto, o acesso aos mesmos é um direito das professoras, das pessoas em geral. Mas isso não é suficiente. Apesar de a Educação Infantil não possuir um caráter instrucional, não tendo, portanto, um currículo predeterminado com conhecimentos e habilidades apresentados numa perspectiva disciplinar, acreditamos, como Aquino (2005, p.10), que "uma relação possível entre a Educação Infantil e os saberes das disciplinas é que estes sirvam de repertório e ferramenta das professoras para que compreendam e alimentem as ações das crianças em relação ao mundo natural e cultural". Assim consideramos que as futuras investigações devem aprofundar discussões relativas a como a proposta de ensino por investigação se articula com as propostas curriculares da Educação Infantil e com as propostas de formação e desenvolvimento profissional das professoras. Do ponto de vista da criança, essa investigação nos convida a pensar futuras pesquisas que tratam das interações das crianças e seus movimentos epistêmicos ao se deparar com processos investigativos. No que se refere à formação de professores, cabe investigar os saberes mobilizados pela professora quando desenvolve atividades investigativas em sala de aula.

Ao longo da interação com as crianças, Amanda desenvolveu uma escuta ativa referente a temas das ciências. Assim, ela passou a dar mais atenção às questões que as crianças levantavam, o que a levou a construir um espaço em sala de aula mais rico para o ensino e aprendizagem de ciências. Isso aponta para a necessidade de repensar algumas questões no processo de formação inicial das professoras. É preciso que, durante sua formação inicial, as professoras se engajem em atividades significativas com as crianças, como recurso de formação, ajudando-as a perceber o modo próprio das crianças pequenas lidarem com temas científicos.

Os saberes profissionais dificilmente se constroem no isolamento, pois assim como a qualidade das interações nas práticas sociais da sala de aula potencializam a construção de conhecimentos para os participantes, as interações estabelecidas entre a professora e seus pares podem operar no mesmo sentido. Portanto, construir uma rede 
de interações alargadas, com seus pares e outros atores ligados aos temas e espaços da educação infantil e das ciências da natureza pode qualificar e fortalecer a docência.

\section{Agradecimentos}

A primeira autora desse artigo agradece as professoras Danusa Munford e a Celi Rodrigues Chaves Dominguez pelas valiosas trocas em pesquisa anterior, que muito contribuíram para a concepção desse artigo.

\section{Referências}

Aquino, L. L. (2005) Professoras de Educação Infantil e saber docente. Revista TEIAS. 6(11-12), 1-12

Carlsen, S. (1991). Effects of new biology teachers' subject-matter knowledge on curricular planning, Science Education, 75(6), 631-647.

Carvalho, A. M. P. (org.) (1998). Ciências no ensino fundamental: O conhecimento físico. Scipione.

Charpak, G. (1996). As ciências na escola primária: Uma proposta de ação. Inquérito.

Colinvaux, D. (2004). Ciências e crianças: Delineando caminhos de uma iniciação às ciências para crianças pequenas. Contrapontos. 4(1), 105-123.

Coutinho, F. A, Goulart, M. I. M., \& Pereira, A. F. (2017). Aprendendo a ser afetado: contribuições para a Educação em Ciências na Educação Infantil. Educação em Revista, 33, e155748. https://dx.doi.org/10.1590/0102-4698155748

Derdyk, E. (1994). Formas de pensar o desenho. Desenvolvimento do grafismo infantil. São Paulo: Scipione.

Dewey, J. (2002). A escola e a sociedade, a criança e o currículo. Lisboa: Relógio d'agua.

Eshach, H. (2006). Science literacy in primary schools and pre-schools. Springer: Dordrecht.

French, L. A., \& Woodring, S. D. (2013). Science education in the early years. In Saracho, O. N. E. SpodekP, B. Handbook of research on the education of young children. (pp. 179196). New York: Routledge,

Fumagalli, L. (1998). O ensino de ciências naturais no nível fundamental de educação formal: Argumentos a seu favor. In Weissmann, H. (Org.). Didática das ciências naturais: contribuições e reflexões. Porto Alegre: ArtMed.

Gelman, R., \& Brenneman, K. (2004). Science learning pathways for young children. Early Childhood Research Quarterly, 19, 150-158.

Gil Pérez, D., Montoro, I. F., Carrascosa, J., Cachapuz, A., \& Praia (2001). Para uma imagem não deformada do trabalho científico. Ciência \& Educação, 7(2), 125-153. 
Golby, M., Martin, A., \& Porter, M. (1995). Some researchers' understanding of primary teaching: comments on Mant and Summers 'Some primary school teachers' understanding of the Earth's place in the universe.' Research Papers in Education, 10, 3, 297-302.

Goulart, M. I. M., \& Roth, W-M. (2010). Engaging young children in collective curriculum design. Cultural Studies of Science Education.

Greenfield, D. B., Jirout, J., Dominguez, X., Greenberg, A., Maier, M., \& Fuccilo, J. (2009). Science in the preschool classroom: A programmatic research agenda to improve science readiness. Early Education and Development. 5(3), 533-562.

Hodson, D. (1992). In search of a meaningful relationship: an exploration of some issues relating to integration in science and science education. International Journal of Science Education, 14(5), 541-562.

Kamii, C., \& Devries, R. (1985). O conhecimento físico na educação pré-escolar: implicações da teoria de Piaget. Porto Alegre: Artes Médicas.

Lee, O. (1995) Subject matter knowledge, classroom management, and instructional practices in middle school science classrooms, Journal of Research in Science Teaching, 32(4), 423-440.

Lima, M. E. C. C., \& Santos, M. B. L. (2015). Ciências da Natureza na Educação Infantil. Belo Horizonte: Fino Traço.

Lima, M. E. C. C., \& Maués, E. (2006). Uma releitura do papel da professora das séries iniciais no desenvolvimento e aprendizagem de ciências das crianças. Revista Ensaio, 8(2), 161-175.

Lima, M. E. C. C., \& Santos, M. B. L. (2013). Trilhas para ensinar ciências para crianças. Belo Horizonte: Fino Traço.

Metz, K. E. (1995). Reassessment of developmental constraints on children's science instruction. Review of Educational Research, 65, 93-127.

Monteira, S. F., \& Jiménez-Aleixandre, M. P. (2015). The Practice of Using Evidence in Kindergarten: The Role of Purposeful Observation. Journal of Research in Science Teaching, 52(6), 1-27. https://dx.doi.org/10.1002/tea.21259

Munford. D., \& Lima, C. M. E. C. (2007). Ensinar Ciências por investigação: Em que estamos de acordo? Revista Ensaio: Pesquisa em Educação em Ciências. 9(1), 89-111. https://dx.doi.org/10.1590/1983-21172007090107

Neves, V. F. A., Munford, D., Coutinho, F. A., \& Souto, K. C. N. (2017). Infância e Escolarização: a inserção das crianças no ensino fundamental. Educação e Realidade, 42, 345-369.

Oliveira, V. B. (org) (2000). O brincar e a criança do nascimento aos seis anos. Petrópolis, RJ: Vozes. 
Piaget, J. (1970). Epistemologia Genética. Abril Cultural.

Piekny, J., Grube, D., \& Maehler, C. (2014). The development of experimentation and evidence evaluation skills at preschool age. International Journal of Science Education 36(2), 334-354.

Roth, W. M., Goulart, M. I., \& Plakitsi, K. (2013). Science Education during early childhood: a Cultural-historical perspective. Heidelberg: Springer.

Sá, E. F. Discursos de Professores sobre Ensino de Ciências por Investigação. $1^{\text {a }}$. ed. São Paulo: Novas Edições Acadêmicas.

Sá, E. F., Lima, M. E. C. C., \& Aguiar, O. G. (2011). A construção de sentidos para o termo ensino por investigação no contexto de um curso de formação. Investigações em Ensino de Ciências. 16(1), 72-102.

Sandoval, W. A. (2005). Understanding Students' Practical Epistemologies and Their Influence on Learning Through Inquiry. Science Education, 89(4) 634-656.

Sandoval, W. A., Sodian, B., Koerber, S., \& Wong, J. (2014) Developing Children's Early Competencies to Engage With Science, Educational Psychologist, 49(2), 139-152. https:// dx.doi.org/10.1080/00461520.2014.917589

Sasseron, L. H., \& Carvalho, A. M. P. (2008). Almejando a alfabetização científica no ensino fundamental: a proposição e a procura de indicadores do processo. Investigações em Ensino de Ciências, 13(3), 333-352.

Schoon, K. J., \& Boone, W. J. (1998). Self-Efficacy and alternative conceptions of science of preservice elementary teachers. Science Education, 82(5), 553-568.

Viecheneski, J., \& Carletto, M. (2013). Por que e para quê ensinar ciências para crianças. Revista Brasileira de Ensino de Ciências e Tecnologia, 6(2), 213-227.

Vygotsky, L. S. (1991). Pensamento e Linguagem. Rio de Janeiro: Martins Fontes.

Vygotsky, L. S. (1996). A formação social da mente. Rio de Janeiro: Martins Fontes.

Vygotsky, L.S. (2001). A construção do pensamento e da linguagem. São Paulo: Martins Fontes. 


\section{Carla Maline}

https://orcid.org/0000-0001-9431-733X Prefeitura Municipal de Belo Horizonte Diretoria Regional de Educação Pampulha Belo Horizonte, Minas Gerais, Brasil carlamaline@yahoo.com.br

Eliane Ferreira de Sá https://orcid.org/0000-0002-0115-9799 Universidade do Estado de Minas Gerais

Unidade Ibirité Belo Horizonte, Minas Gerais, Brasil elianefs@gmail.com

Ely Maués

${ }^{0}$ https://orcid.org/0000-0003-2695-7196 Universidade do Estado de Minas Gerais

Faculdade de Educação Belo Horizonte, Minas Gerais, Brasil elymaues@gmail.com

Alessandra de Caux Souza

http://orcid.org/0000-0001-6361-9925 Prefeitura Municipal de Belo Horizonte Belo Horizonte, Minas Gerais, Brasil decaux51@gmail.com

Submetido em 01 de Fevereiro de 2018 Aceito em 10 de Outubro de 2018 Publicado em 15 de Dezembro de 2018 